\title{
RESEARCH OF CRANBERRY MAIN INDICATORS OF CHEMICAL COMPOSITION AND ITS PROCESSING PRODUCTS
}

\author{
Galyna Khomych \\ Departament of Food industry technologies and restaurant industry \\ Poltava University of Economy and trade \\ 3 Kovalay str., Poltava, Ukraine, 36014 \\ homichgp27@ukr.net \\ Yuliia Matsuk \\ Department of Food Technologies \\ Oles Honchar Dnipro National University \\ 72 Gagarina ave., Dnipro, Ukraine, 49010 \\ lyly2006@ukr.net \\ Julia Nakonechnaya \\ Departament of Food industry technologies and restaurant industry \\ Poltava University of Economy and trade \\ 3 Kovalay str., Poltava, Ukraine, 36014 \\ nakonechna4554@gmail.com \\ Natalia Oliynyk \\ Departament of Food industry technologies and restaurant industry \\ Poltava University of Economy and trade \\ 3 Kovalay str., Poltava, Ukraine, 36014 \\ nataliy_oleinik1963@ukr.net \\ Lolita Medved \\ Departament of Food industry technologies and restaurant industry \\ Poltava University of Economy and trade \\ 3 Kovalay str., Poltava, Ukraine, 36014 \\ lolita.medved@ukr.net
}

\footnotetext{
Abstract

It is well-known that cranberry is an especially rich and heterogenic source of phytochemical substances. Modern technologies allow to produce food products of wild fruits and berries, but they use their diverse and useful chemical composition insufficiently. The aim of the work was in studying features of the chemical composition and content of biologically active substances in cranberries, harvested at the territory of Ukraine, and the influence of processing technologies of cranberry on main indicators of its chemical composition at producing juices.

It was established, that the maximal extraction of biologically active substances is possible at juices production using biocatalysis method, because the essential part of functional elements in the raw material is in the bound condition and is a base of cellular walls that is why it is expedient to disturb nativity and integrity of these natural biopolymers.

There was experimentally grounded the influence of a processing technology on the quality of cranberry juice. There was studied the phenol composition of cranberry composition and influence of different ways of fermentolysis on PS extraction.

It was confirmed by results of the study of the fraction composition of phenol substances, that their maximal extraction is achieved after the enzymatic processing of pulp and momentary heating to inactivate the effect of enzymatic preparations.

It was proved, that enzymatic biocatalysis of cranberry pulp also favors the essential increase of the output of organic acids (lemon, apple, amber), sugars (fructose, glucose), sorbite polyalcohol and also phenol substances of cranberries. The mechanism of the enzymatic complex influence on cranberry pulp at fermentolysis was demonstrated.

The use of products of cranberries processing at food products manufacturing will allow: to enrich the chemical composition, to compensate deviations of functional-technical properties of the raw material and to introduce resource-saving technologies.
} 
Based on the researches there were substantiated perspectives of using juices and marc of cranberry in different branches of the food industry: non-alcoholic, meat processing and at manufacturing products of the restaurant industry.

Keywords: enzymatic preparations, phenol substances, anthocyans, cranberries, cranberry juice.

\section{Introduction}

The one of main conditions of the human organism functioning corresponding to the theory of rational and balanced nutrition, accepted in the international practice, is the compulsory presence of biologically active substances (BAS), such as vitamins, phenol compounds, carotenoids and other in the food ration [1]. The main source of BAS is fruits, vegetables, processing products and functional products with their use.

The important place among vegetable raw materials, contained the essential amount of BAS, belongs to wild berries - natural vitamin-carriers that different treating-prophylactic properties are typical to $[2,3]$.

Modern technologies allow to produce food products of wild fruits and berries, but they use their diverse and useful chemical composition insufficiently. At processing wild berries it must be taken into account that they have more dense morphological structure, lowered ability to juice extraction. At traditional ways of processing berries, both cultivated and wild ones, there are observed essential losses of BAS that results in the decrease of the quality of received products (BAS losses are $20 \ldots 80 \%)[4-8]$.

In this connection studies, connected with the use of promising ways of berries preliminary processing for enriching a ready product with the biologically active raw material complex, are urgent.

\section{Review of the problem}

The development of industrial manufacturing of food products advances on the first place the necessity to create resource-saving technologies that allow to use the food raw material potential more effectively [9].

Wild berries are the high-technological raw material, processed by diverse ways that allow to get semi-products that can be used as food products, ready for consumption [3, 6-8]. Cranberry is an especially rich and heterogenic source of phytochemical substances. More than 150 individual phytochemical substances that demonstrate the high biological activity, functional properties and treating-prophylactic effect, are revealed in it [10-11].

Cranberries are remarkable not only for the high content of dyeing substances of anthocyan origin but also for their stable and durable dyeing properties [12-14]. The one of most progressive ways of the raw material processing is juices production [15]. But a defect at their production is existent regimes of the raw material technical processing that have rather rigid parameters that result in the decrease of the quality of a ready product because of the essential loss of valuable biologically active and dyeing substances.

The use of enzymatic preparations is the most effective way of the preliminary processing of the dark-colored fruit-berry raw material in the world and Ukrainian practice. Their use allows to accelerate the speed of technological processes, to raise the food value at the expanse of enriching with phenol compounds and dyeing substances [16].

The crucial value in the mechanism of stability of the wild berries complex belongs to the fraction composition of polyphenols of the raw material, which change is influenced by the cultivation region and technological methods of the raw material processing [17]. But the influence of enzymatic processing methods on phenol substances (PS) extraction is not studied.

The aim of the work is in the study of the influence of the processing technology of cranberries on main indicators of the raw material chemical composition at juices production that allows to get food products of the high biological value by the maximal PS extraction from the raw material and its enrichment with BAS. 
The following tasks were set for attaining this aim:

- to study features of the chemical composition and BAS content in cranberries, harvested at the territory of Ukraine;

- to determine the expedience of using biocatalytic methods of cranberries processing at juices production for the maximal extraction of BAS;

- to study the fraction composition of PS and influence of different methods of enzymatic catalysis on their extraction.

\section{Materials and methods}

\section{1. Standard methods of studies of physical-chemical indicators of cranberry and products} of its processing

The biological activity indicator in juices was determined by the method of control of the electron-transport activity of juices, beverages, extracts in the system of renewed nicotinamide adenine nucleotide $\left(\mathrm{NAD} \times \mathrm{H}_{2}\right)$ - potassium ferrocyanide in the phosphate buffer $(\mathrm{pH} 7,5)$ [18].

$\mathrm{NAD} \times \mathrm{H}_{2}$ is a co-enzyme with the universal biological role and presents the first link in the chain of transferring an electron and proton from an oxidizing substrate. At the interaction of renewed nicotinamide adenine nucleotide with potassium ferrocyanide, phenol compounds that have electron-transport properties are catalyzed in the phosphate buffer of the electrons transfer. The transfer speed depends on their nature and concentration:

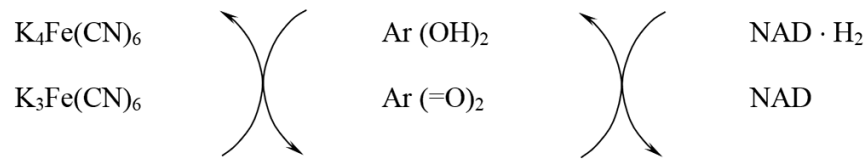

The value of the biological activity indicator was determined by the colorimetric method at the wave length $325 \mathrm{~nm}$ and thickness of the absorbing layer of a dish $10 \mathrm{~mm}$ [18].

Biological activity was calculated by the ratio of $\mathrm{NAD} \times \mathrm{H}_{2} / \mathrm{NAD}$ oxidation speed change in the control experiment and experimental sample taking into account the dilution by the formula:

$$
\text { Б. }=\frac{\left(\mathrm{A}_{0}^{\text {Д }}-\mathrm{A}_{120}^{\text {Д }}\right) \cdot \mathrm{V} \cdot \mathrm{K}}{\left(\mathrm{A}_{0}^{\mathrm{K}}-\mathrm{A}_{120}^{\mathrm{K}}\right) \cdot \mathrm{m}}, \text { con., un. act., } \mathrm{Ba}
$$

where $A_{0}^{\text {Д }}$ - initial optic density of the experimental system; $A_{120}^{\text {I }}$ - optic density of the experimental system in $120 \mathrm{~s} ; A_{0}^{K}$ - initial optic density of the control system; $A_{120}^{K}$ - optic density of the control system in $120 \mathrm{~s} ; \mathrm{V}$ - volume of a volumetric flask, $\mathrm{cm}^{3} ; \mathrm{K}$ - degree of the extraction dilution in distilled water; $\mathrm{m}$ - raw material batch, $\mathrm{g}$.

\section{2. Method of chromatographic studies at identification of PS, organic acids and sugars}

The identification of PS of berries and cranberry juices was realized by the method of high effective liquid chromatography. For realizing the analysis, there was used a chromatographic column with the size $2,1 \times 150 \mathrm{~mm}$, filled with octadecylsilyl sorbent, grains $-3,5 \mathrm{mcm}$, "ZORBAX-SB C-18" (USA).

The parameters of the spectrum survey - each peak $190 \ldots 600 \mathrm{~nm}$, measurement scale 1,0 , scanning duration $2 \mathrm{~s}$, wave length: $313 \mathrm{~nm}$ (phenol and derivative acids), $350 \mathrm{~nm}$ (flavon glycosides), $371 \mathrm{~nm}$ (flavons), $525 \mathrm{~nm}$ (anthocyans); for the fluorescent detector - extinction $280 \mathrm{~nm}$, emission $320 \mathrm{~nm}$ (catechins and epicatechins).

The identification of phenol compounds was realized by the time of keeping standards and spectral characteristics compared with literary data of the high-effective liquid chromatography of studying berries and juices [19-21].

The content of organic acids and sugars was determined by the method of the high-effective liquid chromatography on a chromatograph Agilent Technologies (model 1100) (USA). A carbohy- 
drate chromatographic column with the size $7,8 \times 300 \mathrm{~mm}$, "Supelcogel-C610H" (USA) was used for the analysis.

The following chromatographing regime was set for the analysis: the speed of a movable phase feed $0,5 \mathrm{ml} / \mathrm{min}$; water eluent $0,1 \%$ solution of $\mathrm{H}_{3} \mathrm{PO}_{4}$; working pressure of the eluent $33 . . .36 \mathrm{kPa}$; temperature of the column thermostat $30{ }^{\circ} \mathrm{C}$; sample volume $5 \mathrm{mcl}$.

The following parameters of the spectrophotometric detecting were set: wave length $210 \mathrm{~nm}$; fissure width $8 \mathrm{~nm}$; scanning time $0,5 \ldots 1,0 \mathrm{~s}$. The identification of organic acids and sugars was realized by the time of keeping correspondent standards.

Sample-preparation for the analysis of sugars and organic acids in the raw material. Approximately $5 \mathrm{~g}$ of fruit pulp was weighted in a volumetric flask of $10 \mathrm{~cm}^{3}$ with distinctness up to $0,1 \mathrm{mg}$ and added with water to a mark. After $30 \mathrm{~min}$ of keeping in the ultrasound bath, the solution was filtered through a membrane Teflon filter with the pores size $0,45 \mathrm{mcm}$ in a vial for the analysis.

Sample-preparation for the analysis of sugars and organic acids in juices. The studied sample was centrifuged and filtered through a membrane filter with the pores sizes $0,45 \mathrm{mcm}$ in a vial for the analysis.

For indentifying components there was use a library of mass-spectrums associated with programs for AMDIS and NIST identification. The internal standard method is used for quantitative calculations [19].

\section{Experiments}

Marshy cranberry in the stage of consumption ripeness, harvested in Western and Northern regions of Ukraine, was studied by organoleptic and physical-chemical indicators. Cranberry juice was received by pressing of comminuted cranberry (control sample) and after processing by different ways of enzymatic catalysis (F1, F2, F3) [22].

The studies determined the effectiveness of using the multi-enzyme composition (MEC) of enzymatic preparations, based on enzymes of pectofoetidine and celoterin for the preliminary processing of cranberries.

The regimes of the preliminary processing of cranberry pulp by the multi-enzyme complex of enzymatic preparations of pectolytic and cellulolytic effect: ratio of enzymatic preparations in MEC-1: 7 (Pectofoetidine P20x:Celoterin G3X), temperature $50{ }^{\circ} \mathrm{C}$, duration $60 \mathrm{~min}$.

There were studied different ways of fermentolysis of pulp for phenol and anthocyan substances extraction from the raw material for determining the influence of a combining way at fermentolysis on activity of endo- and exoenzymes. Cranberry pulp was processed by MEC, based on enzymes of pectofoetidine and celoterin (variants F1, F, F3) and obtained results were compared with a control sample (C1). Enzymatic samples: F1 - the complex of enzymes was introduced in prepared pulp and kept during $60 \mathrm{~min}$ at the fermenting temperature $50{ }^{\circ} \mathrm{C}$; F2 - pulp was preliminary heated to the temperature $85 \pm 5^{\circ} \mathrm{C}$, cooled to the fermenting temperature and the complex of enzymes was introduced; F3 - pulp was heated after fermenting at the temperature $50{ }^{\circ} \mathrm{C}$ to the temperature $85 \pm 5^{\circ} \mathrm{C}$, cooled and pressed. Preliminary studies established parameters of enzymatic catalysis and their influence on the juice extraction $[22,23]$.

\section{Results}

The organoleptic indicators of cranberries were: the round form, red color, specific taste and smell, typical for the raw material.

The analysis of the chemical composition of cranberries (Table 1) demonstrated that cranberry is a rich source of biologically active compounds.

Table 1

Physical-chemical indicators of cranberries $(n=3, p \leq 0,05)$

\begin{tabular}{ccccc}
\hline & & Mass share, $\%$ & & \\
Dry substances & sugars & pectin & protopectin & cellulose \\
\hline 13,20 & 3,65 & 0,77 & 0,35 & 1,80
\end{tabular}


Cranberries has $86 \ldots 87 \%$ of water in their composition and have rather high titrated acidity. Carbohydrates are the important component of organic compounds in the composition of cranberry. Polysaccharides of cranberry consist mainly of pectin substances, cellulose.

At the studies it was established, that lemon acid and also apple and amber ones dominate in cranberries that raise antioxidant properties of berries.

According to the results of the experimental studies, cranberries are characterized by the rather high index of biological activity (2840,00 con. un. of act). L-ascorbic acid was revealed in analyzed samples $(16,60 \mathrm{mg} / 100 \mathrm{~g})$, dyeing $(48,70 \mathrm{mg} / 100 \mathrm{~g})$ and phenol $(90,00 \mathrm{mg} / 100 \mathrm{~g})$ substances.

It was established, that PS fraction composition in cranberries is presented by oxycoric acids and their derivatives $(19,46 \mathrm{mg} / 100 \mathrm{~g})$, flavons and their derivatives $(24,44 \mathrm{mg} / 100 \mathrm{~g})$, anthocyans (43,40 mg/100 g).

But the essential part of physiological-functional ingredients in berries is in the bound condition. Main chemical components of the cellular wall are organic substances, unessential part are mineral substances. Pectin substances in vegetable cells are in two main forms: soluble pectin (hydropectin) and insoluble (protopectin) that is a strong compound of pectin with cellulose.

For disturbing integrity of natural biopolymers, it is most effective to use enzymes of the complex effect with pectolytic and cellulolytic activity for the preliminary processing.

There was studied the fraction composition and influence of different ways of fermentolysis on phenol compounds extraction at receiving juice (Fig. 1).

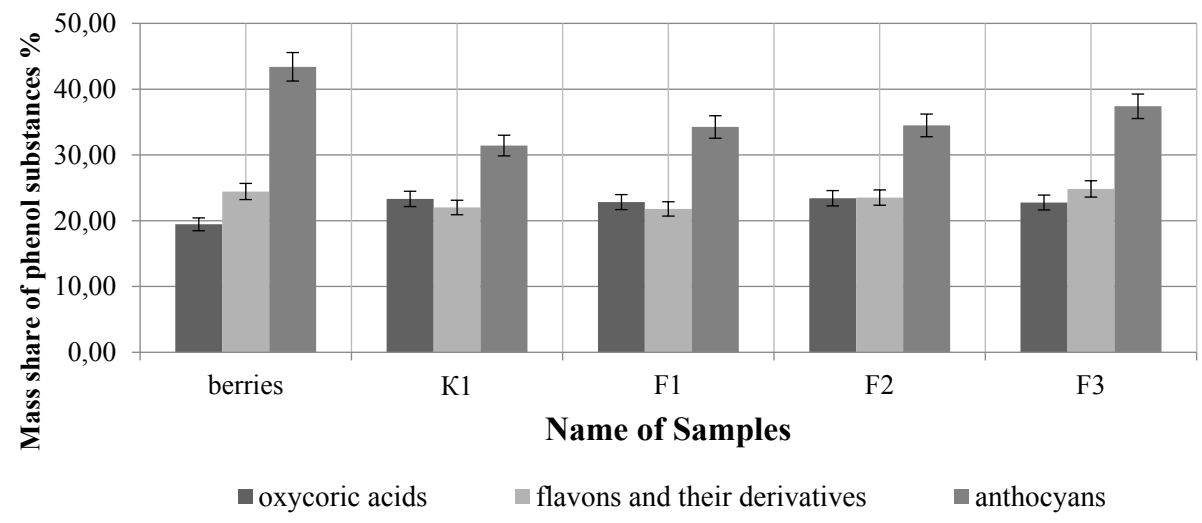

Fig. 1. Influence of preliminary processing of cranberry on PS extraction at receiving juices

It was determined, that the composition of phenol compounds is presented by oxycoric acids, flavons and their derivatives and anthocians.

Myricetin-3-o-arabinoside, quercetin-3-o-galactoside, quercetin-3-o-arabinoside, quercetin-3-o-rhamnoside, camppherol-3-o-glycoside and camppherol derivatives were identified in the group of flavons and their derivatives by the fraction composition. Coffee and vanillin acids were identified in the group of oxycoric acids.

Anthocyans prevail in cranberries among flavonoids, their content is $64 \%$ of the content of phenol compounds. Anthocyans of cranberry are presented by glycosides of cyanidin and glycosides of peonidin with three carbohydrates - glucose, galactose and arabinose. Peonidin glycosides dominate in cranberries, their share is $61,0 \%$ of the total content of anthocyans, peonidin-3-o-galactoside prevails. The share of cyanidin glycosides is $39 \%$ of the total content of anthocyans, cyandinin-3-o-galactoside prevails.

It was established, that best results for the maximal PS extraction are achieved by the fermenting method F3. PS transition in juice at such processing method is $97,4 \%$ of their content in the raw material. Method F3 gives best results for flavons and their derivatives and anthocyans, and in the case of oxycoric acids the maximal extraction is achieved at method F2.

At the enzymatic processing of cranberry pulp the content of organic acids increases comparing with the control: lemon acid - from 1,2 to $1,9 \%$; apple - from 0,5 to $0,7 \%$; amber - from 0,2 to $0,3 \%$. The use of the preliminary enzymatic processing results in the destruction of the organic 
matrix of the cellular wall of the vegetable raw material, and the part of organic acids transforms from the bound condition into the free form. The presence of amber acid in juices and its content increase in the process of fermentolysis raises antioxidant properties of a ready product.

The quality of juices is greatly influenced by sugars, which presence together with organic acids conditions a taste and energetic value of beverages. The enzymatic processing use increases the sugars content in juice: fructose - by $25,8 \%$; glucose - by $18,4 \%$ comparing with the control sample. The sorbite extraction from the raw material in juice is also increased almost in 2,0 times comparing with the control. It undoubtedly plays a positive role and gives juices prophylactic properties.

\section{Discussion of results}

The study of the cranberry chemical composition (Table 1) proved that this raw material is a natural source of BAS, extremely important for the human organism.

It was established, that the maximal BAS extraction is possible at producing juices by biocatalysis methods, because the important share of functional ingredients in the raw material is in the bound condition and is a base of cellular walls that is why it is expedient to destruct nativity and integrity of these natural biopolymers. The introduction of method F3 in production allows to extract the PS content of cranberries in juice maximally (up to $97 \%$ ).

The mechanism of the influence of enzymes complex on cranberry pulp at fermentolysis is following: as a result of the effect of pectolytic enzymes there takes place the disintegration of tissues to separate cells, splitting of the cellular wall. Pectolytic enzymes split cross bridges that combine D-galacturonans with hemicelluloses that cover microfibrils of cellulose and make them accessible for cellulolytic enzymes that favor insoluble protopectin transformation into the soluble form. Without the modification of the cellular wall by pectolytic enzymes, other enzymes that affect polysaccharides cannot attack their substrates.

The enzymatic biocatalysis of cranberry pulp also favors the essential increase of the output of organic acids and sugars in the soluble part of juices, allows to extract phenol compounds (anthocyans) of cranberries maximally, so it is expedient to use the offered processing type in technologies of products of health-improving destination. But it was established, that the essential amount of BAS remains in cranberry marc and is wasted.

Based on the research results, it was offered to use the complex processing of cranberries and there were separated fields of using received cranberry juices in recipes of fruit juices for establishments of the restaurant industry, and the high content of dyeing substances in marc allows to use them at producing non-alcoholic gas beverages as natural coloring agents; in the meat processing industry - at pastes production.

\section{Conclusion}

As a result of the studies:

- the chemical composition of cranberries, harvested at the territory of Ukraine, was determined; the high PS content was revealed in it;

- it was proved, that the preliminary processing of cranberry pulp by the complex of enzyme preparations of pectolytic and cellulolytic effect increases the total content of compounds that form the juices quality: organic acids (lemon, apple, amber), sugars (fructose, glucose), sorbite polyalcohol and also PS;

- the results of the study of the PS fraction analysis proved that PS maximal extraction is achieved after the enzymatic processing of pulp and its momentary heating to inactivate the effect of enzymatic preparations (sample F3).

Based on the researches there were substantiated perspectives of using juices and marc of cranberry in different branches of the food industry: non-alcoholic, meat processing and at manufacturing products of the restaurant industry.

The perspective of further studies in this direction is a test of the improved technology of juices production in industrial conditions. 


\section{References}

[1] Kapreliants, L. V., Iorhachova, K. H. (2003). Funktsionalni kharchovi produkty. Odesa: Druk, 312.

[2] Celik, H., Ozgen, M., Serce, S., Kaya, C. (2008). Phytochemical accumulation and antioxidant capacity at four maturity stages of cranberry fruit. Scientia Horticulturae, 117 (4), 345-348. doi: 10.1016/ j.scienta.2008.05.005

[3] Obolkina, V. I., Syvnii, I. I., Oleksiienko, N. V. (2016). Zastosuvannia napivfabrykativ z dykoroslykh plodiv ta yahid dlia podovzhennia terminu prydatnosti kondyterskykh vyrobiv. Materialy V Mizhnarodnoi spetsialnoi naukovo-praktychnoi konferentsii «Resurso- ta enerhooshchadni tekhnolohii vyrobnytstva i pakuvannia kharchovoi produktsii - osnovni zasady yii konkurentozdatnosti». Kyiv: NUKhT, 124-125.

[4] Kozhukhivska, I. M., Stetsenko, N. O. (2016). Doslidzhennia sposobiv pereroblennia yahid zhuravlyny dlia vyrobnytstva naturalnykh zbahachuvachiv kyslomolochnykh napoiv. Materialy 82 mizhnarodnoi naukovoi konferentsii molodykh uchenykh, aspirantiv i studentiv «Naukovi zdobutky molodi - vyrishenniu problem kharchuvannia liudstva u XXI stolitti», 1. Kyiv: NUKhT, 18.

[5] Koshova, V. M., Husieva, O. A., Hordynska, A. I. (2014). Vykorystannia zhuravlyny dlia pryhotuvannia bezalkoholtnykh napoiv. Zbior raportow naukowych «Wspolczesnetendecje w nauce i edukacji». Warszawa: Sp. z o. o. «Diamond trading tour», 44-47.

[6] Bashta, A., Mandziroha, G. (2016). Obtaining health improvement halva. Kharchova promyslovist, 19, 19-24.

[7] Riabokon, N. V., Osmak, T. H. (2014). Obgruntuvannia vyboru plodovo-yahidnykh syropiv $\mathrm{u}$ tekhnolohii zghushchenykh molochnykh konserviv z tsukrom i napovniuvachamy. Zbirnyk naukovykh prats za materialamy II Mizhnarodnoi naukovo-praktychnoi konferentsii NAAN Ukrainy «Prodovolchi resursy: problemy i perspektyvy». Kyiv: National Science Center «Institute of Agrarian Economics», 181-184.

[8] Syvnii, I. I., Volosetska, M. V., Obolkina, V. I. (2016). Rozroblennia tekhnolohii bilkovo-zbyvnoho kremu z pidvyshchenym vmistom biolohichno-aktyvnykh rechovyn, podovzhenym terminom prydatnosti iz zastosuvanniam piure z zhuravlyny. Materialy 82 mizhnarodnoi naukovoi konferentsii molodykh uchenykh, aspirantiv i studentiv «Naukovi zdobutky molodi - vyrishenniu problem kharchuvannia liudstva u XXI stolitti», 1. Kyiv: NUKhT, 160.

[9] Sheremet, O. O., Krivchun, O. M. (2011). Organizational and economic mechanism resource saving the food industry. Naukovi Pratsi NUKhT, 40, 34-39.

[10] Jambrak, A. R., Simunek, M., Petrovic, M., Bedic, H., Herceg, Z., Juretic, H. (2017). Aromatic profile and sensory characterisation of ultrasound treated cranberry juice and nectar. Ultrasonics Sonochemistry, 38, 783-793. doi: 10.1016/j.ultsonch.2016.11.027

[11] Thimoteo, N. S. B., Scavuzzi, B. M., Simao, A. N. C., Dichi, I. (2017). The impact of cranberry (Vaccinium macrocarpon) and cranberry products on each component of the metabolic syndrome: a review. Nutrire, 42 (1), 25-36. doi: 10.1186/s41110-017-0048-8

[12] Celik, H., Ozgen, M., Serce, S., Kaya, C. (2008). Phytochemical accumulation and antioxidant capacity at four maturity stages of cranberry fruit. Scientia Horticulturae, 117 (4), 345-348. doi: 10.1016/ j.scienta.2008.05.005

[13] Caillet, S., Cote, J., Doyon, G., Sylvain, J.-F., Lacroix, M. (2011). Antioxidant and antiradical properties of cranberry juice and extracts. Food Research International, 44 (5), 1408-1413. doi: 10.1016/ j.foodres.2011.02.019

[14] Hendry, G. A. F., Houghton, J. D. (Eds.). (1996). Natural Food Colorants. Springer US, 348. doi: 10.1007/978-1-4615-2155-6

[15] Jackman, R. L., Smith, J. L. (1996). Anthocyanins and betalains. Natural Food Colorants. Springer US, 244-309. doi: 10.1007/978-1-4615-2155-6_8 
[16] Khomych, H. P., Kapreliants, L. V., Tkach, N. I. (2010). Vykorystannia fermentnykh preparativ dlia pererobky plodovo-yahidnoi dykorosloi syrovyny. Obladnannia ta tekhnolohii kharchovykh vyrobnytstv, 25, 123-128.

[17] Robards, K., Prenzler, P. D., Tucker, G., Swatsitang, P., Glover, W. (1999). Phenolic compounds and their role in oxidative processes in fruits. Food Chemistry, 66 (4), 401-436. doi: 10.1016/s03088146(99)00093-x

[18] Khomych, H. P., Vikul, S. I., Kapreliants, L. V., Osypova, L. A., Lozovska, T. S.; assignee: Odessa National Academy of Food Technologies. (12.01.2015). Sposib vyznachennia biolohichnoi aktyvnosti obiektiv pryrodnoho pokhodzhennia. Patent of Ukraine No. 107506 C2, MPK G 01N 33/00 (2015.01). Appl. No. a 201302626. Bull. No. 1. Available at: http://uapatents.com/7-107506-sposib-viznachennya-biologichno-aktivnosti-obehktiv-prirodnogo-pokhodzhennya.html

[19] Khomych, H. P., Tkach, N. I. (2012). Doslidzhennia tekhnolohichnykh vlastyvostei yahid buzyny chornoi. Obladnannia ta tekhnolohii kharchovykh vyrobnytstv, 28, 387-392.

[20] Chen, H., Zuo, Y., Deng, Y. (2001). Separation and determination of flavonoids and other phenolic compounds in cranberry juice by high-performance liquid chromatography. Journal of Chromatography A, 913 (1-2), 387-395. doi: 10.1016/s0021-9673(00)01030-x

[21] Prior, R. L., Lazarus, S. A., Cao, G., Muccitelli, H., Hammerstone, J. F. (2001). Identification of Procyanidins and Anthocyanins in Blueberries and Cranberries (Vaccinium Spp.) Using High-Performance Liquid Chromatography/Mass Spectrometry. Journal of Agricultural and Food Chemistry, 49 (3), 1270-1276. doi: 10.1021/jf001211q

[22] Khomych, H. P., Yurchishyna, L. M. (2005). Doslidzhennia metodiv poperednoi obrobky zhuravlyny pid chas vyrobnytstva soku. Obladnannia ta tekhnolohii kharchovykh vyrobnytstv, 12 (1), 190-192.

[23] Khomych, H. P., Tkach, N. I., Yurchishyna, L. M. (2006). Vdoskonalennia tekhnolohii vyrobnytstva soku z zhuravlyny. Visnyk KhNTUSH im. P. Vasylenko. Suchasni napriamky tekhnolohii ta mekhanizatsii protsesiv pererobnykh i kharchovykh vyrobnytstv, 45, 330-337. 